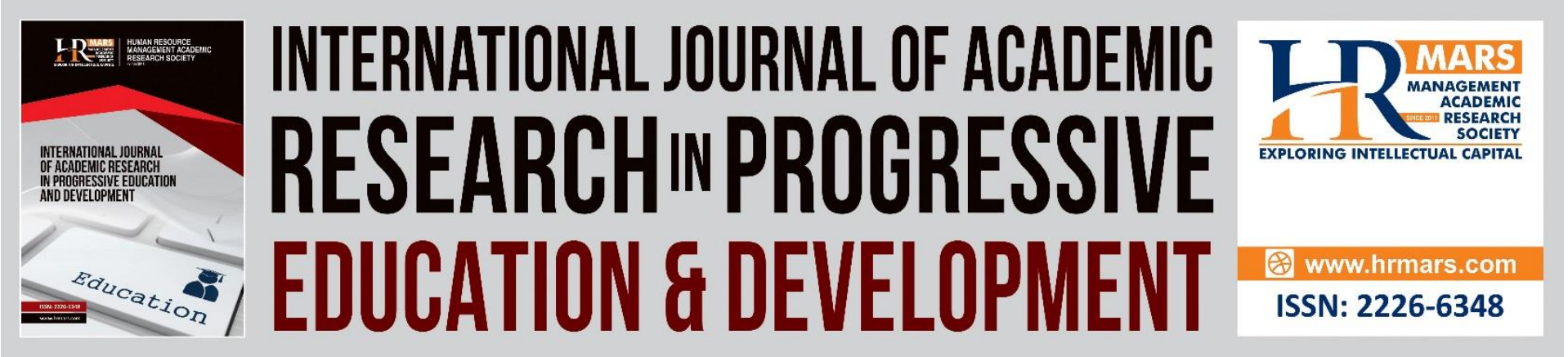

\title{
Boosting Vocabulary Mastery in Primary School Pupils by Revolutionizing Wordwall through C\&K
}

Vanisa Magasvaran, Jennie Ukat, Melor Md Yunus

To Link this Article: http://dx.doi.org/10.6007/IJARPED/v11-i1/11852

DOI:10.6007/IJARPED/v11-i1/11852

Received: 06 November 2021, Revised: 03 December 2021, Accepted: 30 December 2021

Published Online: 08 January 2022

In-Text Citation: (Magasvaran et al., 2022)

To Cite this Article: Magasvaran, V., Ukat, J., \& Yunus, M. M. (2022). Boosting Vocabulary Mastery in Primary School Pupils by Revolutionizing Wordwall through C\&K. International Journal of Academic Research in Progressive Education and Development, 11(1), 72-83.

Copyright: (c) 2022 The Author(s)

Published by Human Resource Management Academic Research Society (www.hrmars.com)

This article is published under the Creative Commons Attribution (CC BY 4.0) license. Anyone may reproduce, distribute, translate and create derivative works of this article (for both commercial and non-commercial purposes), subject to full attribution to the original publication and authors. The full terms of this license may be seen

at: http://creativecommons.org/licences/by/4.0/legalcode

Vol. 11(1) 2022, Pg. 72 - 83

Full Terms \& Conditions of access and use can be found at http://hrmars.com/index.php/pages/detail/publication-ethics 


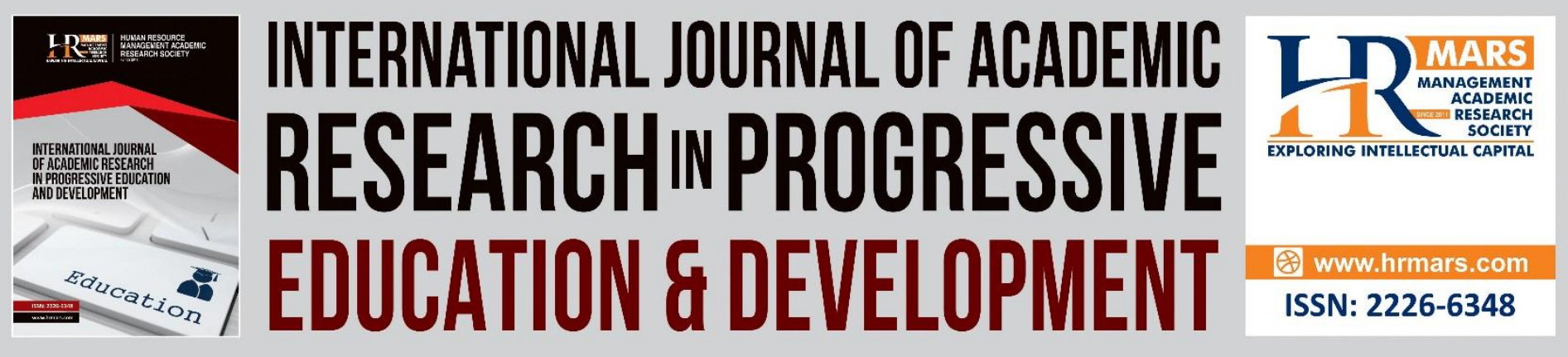

\title{
Boosting Vocabulary Mastery in Primary School Pupils by Revolutionizing Wordwall through C\&K
}

\author{
Vanisa Magasvaran, Jennie Ukat, Melor Md Yunus
}

Faculty of Education, Universiti Kebangsaan Malaysia, UKM Bangi, Selangor, Malaysia

Email: p111807@siswa.ukm.edu.my, p111758@siswa.ukm.edu.my, melor@ukm.edu.my

\begin{abstract}
Interactive online educational games function as an important learning tool in helping young learners to improve their English language vocabulary mastery especially when remote learning is significant during the Covid-19 pandemic. Problems arise when pupils are seen to be struggling with developing new vocabulary. Therefore, in order to improve pupils' vocabulary mastery, this study aims to design, develop and evaluate the effectiveness of using C\&K in an English as Second Language (ESL) classroom. The objective of this research is to see to what extent $C \& \mathrm{~K}$ helps in enhancing vocabulary development. A quantitative study was conducted. It involved 30 primary 3 students, all of which had varying degrees of academic ability. Before the innovation, a pre test was conducted and a post-test was conducted after the innovation. Then, a survey form was used to get feedback from pupils about C\&K. To effectively employ Wordwall as a suitable base for carrying out the desired games, a well organized module is constructed. This idea advocated that well-organized online games be incorporated in ESL lessons since games are a kind of motivation that may capture and hold pupils' attention and knowledge, helping them to become more involved in learning. The preand post-test analysis indicate that C\&K had successfully improved vocabulary knowledge among year 3 pupils. According to the survey, $C \& K$ is reliable and pupil-friendly material for year 3 pupils. As a result, the innovation's significance is that it provides a system of customized games for the teaching and learning of English vocabulary, that is advantageous for learners and teachers.
\end{abstract}

Keywords: Innovation, Covid-19, Primary School Pupils, Wordwall, Vocabulary Mastery

\section{Introduction}

Covid-19 interrupts pupils' lives as it forces them to socially isolate themselves in order to prevent the virus from spreading further. As a result, it has been critical to develop educational technologies that are compatible with remote learning in order to improve remote teaching and learning sessions. As a result, according to Johnson et al., (2020), to ensure that social distancing is practised, nearly all instruction has been shifted to remote education. Online interactions have become feasible as a result of continual advancements in digital technology. As a result, a lot of effort has gone into developing innovative teaching approaches or materials that boost pupils' interest and enthusiasm while simultaneously maximising their knowledge acquisition, especially in ESL classrooms. Madut and Yunus 
(2016) also mentioned that utilizing creative materials in the classroom is a distinct technique of teaching that may benefit students' learning and teaching experiences.

Young learners have the biggest impact upon the The Ministry of Education's (MOE) initiative to transition traditional face-to-face classrooms to virtual learning (Kamarudin, 2020) as they are still building the foundation of their learning experiences. The drawbacks of being socially isolated is that there will be less possibilities of socialization. Young learners also will miss out experiencing the supportive school atmosphere where new vocabulary could be acquired. According to a study by Dong, Chua, and Li (2020), poor learning outcomes are caused by a lack of a learning environment and social interactions for young children. Furthermore, to equip pupils with 21st-century abilities, they should be taught adopting a 21st-century teaching strategy (Pamela et al., 2016), and ICT can be used as a learning tool in education (Yunus et al., 2013). According to Sivagnanam and Yunus (2020), vocabulary study is a comprehensive strategy used for second language acquisition since it is one of the most important components of language learning.

Gamification seems to have the potential to assist students in the learning process more effectively (Koivisto \& Hamari, 2019). According to Vartanian \& Beatty, (2015), games have elements that develop creativity while Toh \& Kirschner, (2020) said that games could enhance information acquisition. Waytz \& Gray, (2018) believes that games could boost one's mental health while, Valkenburg \& Peter, (2009) indicated that it could minimize feeling isolated. Wordwall is one of the easiest methods to gamify education by allowing students to test their knowledge on a platform using various sorts of games as indicated by Cruea, (2020). Wordwall, on the other hand, has a wide variety of games, and teachers must be aware of the "how" in managing a gamified learning environment that is both helpful and productive for young students.

This study focuses on 9-year-old young learners living in an era of social distancing and technology advancing rapidly. Thus, online games have a considerable impact on vocabulary acquisition. It's also pointless to play games for educational reasons if you don't have the right materials. During their learning, pupils are observed to have difficulty developing new words. Hence, C\&K is developed and has been devised by the researchers.

Several studies have been conducted in the past that examine the influence of utilising the Wordwall tool in ESL, such as the publications by Cil (2021); Hasram et al (2021). The significance of this research is that it focuses on an innovative module that provides a new method of improving vocabulary through the use of Wordwall. Teachers will profit from this innovation since it will enable them to use Wordwall in their classrooms in a systematic way. The primary aim of this research is to design, develop, and analyse the efficacy of employing C\&K while adapting the Wordwall platform to help students enhance their vocabulary mastery.

This study would also investigate to what extent C \& $\mathrm{K}$ assists in enhancing vocabulary mastery.

Therefore, this article contains the aspects of designing C\&K, developing C\&K, and evaluating C\&K in vocabulary mastery among 9 years old pupils. Additionally, with this innovation, pupils should be able to improve their gamified learning quality and teachers will have a new means to make better decisions on incorporating Wordwall in their own classroom. The following research questions are further discussed in this study:

1. Does C\&K able to improve English language vocabulary mastery among Year 3 primary school pupils?

2. What are the perceptions of Year 3 primary school pupils' on employing C\&K 
in learning vocabulary?

\section{Literature Review}

\section{Vocabulary in learning the English language}

Listening, speaking, reading, and writing is the foundation of mastering the English language. Vocabulary mastery definity a kick start to mastering the language. As stated by Moody et al., (2018), the procedures of expanding one's vocabulary comprises noticing, retrieving, and creatively using specific terms which are also supported by Kanellopoulou et al., (2019). It does help learners to learn new vocabulary when they come across unexpected words or phrases. Besides, more words are stored and embedded significantly in pupils mind as suggested by (Atikah \& Rezki, 2018; Boers et al., 2017).

According to Anggrarini (2018), 40 percent of vocabulary learning activity involves repeating words always playing in learners' minds. The fact that non-native English Speakers also have problems with new words' meaning, pronunciation, spelling, correct word usage, guessing meaning from a context and other concerns is supported by practitioners. Previous researchers also emphasize that vocabulary acquisition is indeed a difficult task to be integrated. Nejati et al (2018) highlighted that English Second Language (ESL) students with poor lexicon usually encounter hurdles when it comes to common reading comprehension and understanding or applying syntax rules while using the language. Thus, vocabulary mastery is vital for smooth and efficient communication. This statement is also supported by Sidek and Ab. Rahim (2015), states the insufficiency of vocabulary knowledge can affect four language skills, speaking, writing, reading and listening.

\section{Gamification in Learning English}

The concept of introducing digitally programmed games into English language education isn't regarded to be a novel idea. Gamification is described as the use of properties commonly associated with video games in non-gaming environments. When using gamification in the educational context of a second language learner (L2), pedagogical approaches, methods, and techniques apply. The psychological foundations are used by the researchers such as flow theory, self-determination theory, self-efficacy theory, supported by previous studies of gamification by (Cherry, 2017; Tandon, 2017). Combining these three approaches shed light on the advantages of online games or gamification especially in learning language. As presented by Juho Hamari (2017) provided a study that linked game outline and positive motivation in bridging gap between learning theory and gamification elements. This study as stated by Hamari et al (2017) that a significant numbers of dissertations associate study and inspiration increased abruptly for the last eight years period. The number of studies linking learning and motivation has increased significantly over the last eight years, highlighting the interests and potential of gamification. Moreover, immersive online games improve linguistic acquisition which focuses on less knowledgeable $L 2$ secondary school pupils (Andreani and Ying, 2019).

After the induction of portable applications for literary vocabulary acquisition, pupils' mastery in English vocabulary has increased significantly. This statement is also supported by Bakhsh (2016), which stated that the way of human thinking is built around game features, allowing pupils to resolve difficulties and attract pupils in immersive learning. Chapman \& Rich (2018); Anetal (2015); Azli et al (2018) Students have found that they can learn English better with mobile games. As a result, gamification is a fresh insight that fits for learning English, especially vocabulary. 
DEVELOPMENT

Vol. 11 , No. 1, 2022, E-ISSN: 2226-6348 @ 2022 HRMARS

\section{Wordwall and the Learning of English Vocabulary}

Wordwall is the perfect game platform for drilling practicing vocabulary (Hasram, et al.2020) as it provides a variety of game formats that are useful to the selected crowd of pupils, in this scenario primary school pupils. "Teachers can use Wordwall to facilitate word analysis, provide models of word misspelling, and increase the vocabulary of their field of study," says (Brabham and Villaume, 2021). Max Brand (2014) supports this specific idea by indicating that Wordwall supports student vocabulary development. On the other hand, it is critical to select a game that is both amusing and has learning objectives. This is because there are educationally valuable games that are not very fun. Jantke and Hume (2015) are the two authors who wrote about this topic.

Choosing the right resources is essential for thriving implementation theory in learning with mobile learning, as it can bridge the gap between education and joy, attract learners' attention and motivate them to learn. According to Pearson et al. (2017), bridging gaps in vocabulary learning may be accomplished by actively and systematically teaching pupils language. It is necessary to provide an adaptive and coordinated educational system to meet the needs of different learners with different needs and characteristics. In order to deliver customized content, the following four modules are required: the main knowledge and the layout of the system's knowledge database is embedded in the expert module; the pupils workbook is then accountable for gathering important knowledge regarding the student and keeping it in the pupils model; while, the tutoring or the mentoring module is responsible for the needs-based design of learning materials and the interface module for providing the right resources, (Pearson et al., 2017).

\section{Methodology \\ Research Design}

This study uses quantitative survey design to further understand how this C\&K innovation can help students improve their vocabulary skills.

\section{Research Participants}

33 primary school pupils from a public primary school in Malaysia participated in this study. Participants consisted of 14 boys and 16 girls with mixed skills, 16 in band 4 and 14 in band 5, according to the School Based Assessment or Pentaksiran Bilik Darjah (PBD). Participants were selected using the convenience sample method because they attended the same school as the researcher. This made the research much easier and time saver. This action also in line with Sabbah (2015), respondents are selected based on their accessibility to researchers.

\section{Research Instrument}

All the instruments used are validated by one associate professor in Teaching English as Second Language (TESL) field, two senior primary school English language teachers in order to maintain the reliability and validity of the instruments. The instruments used are pre-test done on the beginning of implementing the intervention and then the post-test at the end of implementing the intervention. A survey feedback form is used to collect perceptions of the participants on C\&K.

\section{Data Collection Method and Analysis}

We used a descriptive analysis, a percentage of frequency distribution to analyze data from pre-tests, post-tests, and surveys. In the pretest, there are 25 multiple-choice questions about 
the vocabulary of the textbook Get Smart Year 3. The pretest was developed to assess students' language skills before implementing C\&K through an interactive Wordwall. Next, an post-exam comprising 25 multiple-choice questions (MCQ) was conducted, where the words used are the same with the pre-exam conducted in the next grade. Post-test is important to see how the pupils achieve after applying the innovation C\&K. We further triangulated the data by analysing the document and conducted a survey to collect pupils feedback about the intervention. Feedback survey was distributed by using Google Form which included a 10 item questionnaire that was adapted from Maphosa, Dube, and Jita (2020) by using an integrated technology adoption and the perceived of usefulness theory (UTAUT) framework. Part 1 of the questionnaire asked about the background of the participants, and Part 2 asked their opinions about the innovation C\&K on three scales: Agree, not sure and disagree.

\section{Research Procedures}

ADDIE model is employed to systematically create this innovation. Participants were pretested prior to the innovative intervention. Then, by tailoring structure and contents to the specificities and requirements of the learners, the innovation is then designed and developed. English Year 3, Get Smart Textbook acts as a reference to construct C\&K by utilizing the Wordwall platform. QR codes are used to keep the C\&K modules systematically. The QR codes are also easy to be shared among pupils and it is used to share the materials with the pupils. It is simple to use since pupils simply have to scan QR codes, and teachers may upload all of the necessary learning resources embedded in these codes, (Kar and Kim, 2021).

The first module contains games such as Hangman and also Find the Match. The next module contains Group Sort and the Conveyor Belt. Quiz and the unjumbled activity are used in the third module. Soundtracks, animations, and pictures are all included in these game concepts. The aforementioned notion is supported by the game template and content selection. The pretest is run first and then the first round of intervention takes place in the next class. The consecutive intervention rounds were conducted in the following classes. Innovative interventions are implemented in online classes using the Zoom application throughout the lesson. After that, a post-test was conducted in the next grade. With the help of the questionnaire, student opinions on C\&K innovation were also collected. Picture 1 shows a QR code layout of the innovation, while Picture 2 shows an example of a game created with the Wordwall template. 
INTERNATIONAL JOURNAL OF ACADEMIC RESEARCH IN PROGRESSIVE EDUCATION AND DEVELOPMENT

Vol. 11, No. 1, 2022, E-ISSN: 2226-6348 @ 2022 HRMARS

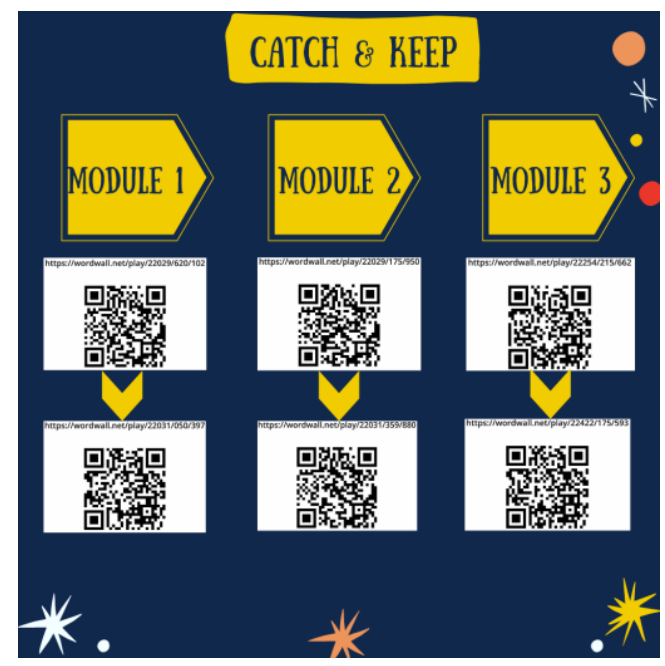

Picture 1: C\&K QR codes layout.

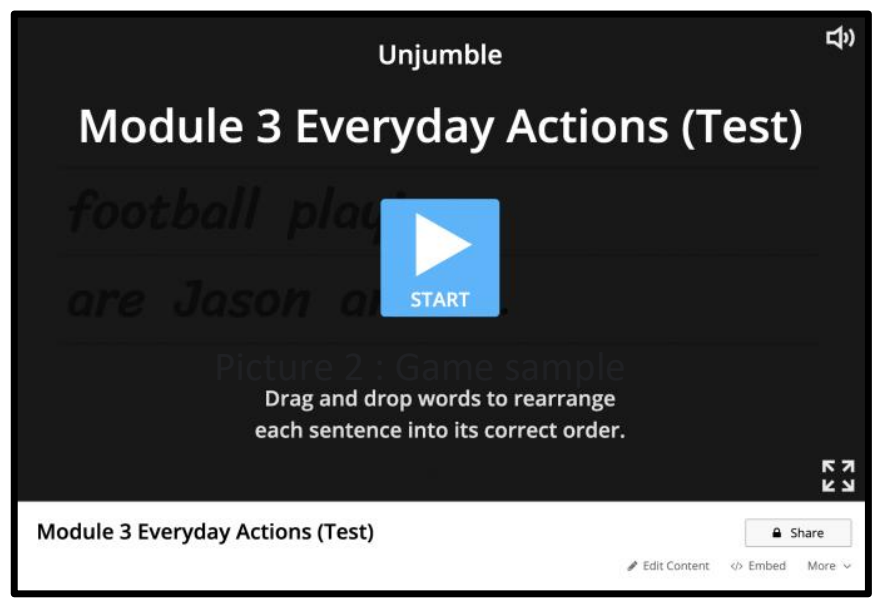


INTERNATIONAL JOURNAL OF ACADEMIC RESEARCH IN PROGRESSIVE EDUCATION AND

DEVELOPMENT

Vol. 11, No. 1, 2022, E-ISSN: 2226-6348 @ 2022 HRMARS

\section{Result and Discussion}

The results and discussion of employing C\&K in improving English language vocabulary in a primary school context are further elaborated below.

\begin{tabular}{cccc}
\hline TABLE 1: PRE-TEST AND POST TEST RESULT & & \\
\hline GRADES & MARKS (\%) & NUMBER OF STUDENTS & \\
\cline { 3 - 4 } & & & PRE-TEST (F) \\
\hline A & & 3 & 28 \\
\hline B & $85-100$ & 3 & 1 \\
\hline C & $70-84$ & 4 & 1 \\
\hline D & $60-69$ & 2 & 0 \\
\hline E & $50-59$ & & 0 \\
\hline F & $40-49$ & 12 & 0 \\
\hline
\end{tabular}

Table 1 : Pre-Test and Post-Test results.

The results for pre-test and post-test are shown in table 1 . The marks are then classified into grades based on the Malaysian educational system. $A$ is the highest grade, followed by B, C, D, E, and F. The last grade, an F, is a failing grade. The students' grades improved considerably after using WordWall to implement "C\&K," with no students obtaining a $\mathrm{F}$ on the post-test, compared to six students failing the vocabulary test on the pre-test.The results show that 28 students received an $A$ on the post-test, but only three received an $A$ on the pre-test. According to Hamari (2017), gamification is a technique for bridging the gap between educational theory and game elements. According to Andreani and Ying (2019), students with low proficiency can enhance their language acquisition abilities by playing interactive online games. Online games integrate reasoning skills to address issues and engage pupils in interactive learning, (Bakhsh, 2016; Chapman \& Rich, 2018). As a result, gamification is a reliable and relevant idea or concept for application in English language acquisition, especially vocabulary mastering. As a result of the improvement in score, C\&K appeared to have a favourable impact on students' ESL vocabulary mastery. 


\begin{tabular}{|c|c|c|c|}
\hline QUESTIONS & $\begin{array}{c}\text { AGREE } \\
(\%)\end{array}$ & $\begin{array}{c}\text { NOT SURE } \\
\text { (\%) }\end{array}$ & $\begin{array}{c}\text { DISAGREE } \\
(\%)\end{array}$ \\
\hline \multicolumn{4}{|l|}{ PERFORMANCE EXPECTANCY } \\
\hline 1.Using "Catch and Keep" through Wordwall improves my vocabulary. & 100 & & \\
\hline \multicolumn{4}{|l|}{ English vocabulary. } \\
\hline \multicolumn{4}{|l|}{ EFFORT EXPECTANCY } \\
\hline 3. I find "Catch and Keep" through Wordwall is easy to use. & 96.67 & & \\
\hline 4. I am not comfortable using "Catch and Keep" through Wordwall. & & 3.33 & 96.67 \\
\hline \multicolumn{4}{|l|}{ SOCIAL INFLUENCE } \\
\hline 5. I think that "Catch and Keep" through Wordwall platform is an updated learning style. & 100 & & \\
\hline 6. My teacher, family and friends supports me to use "Catch and Keep" through Wordwall & 76.67 & 23.33 & \\
\hline \multicolumn{4}{|l|}{ FACILITATING CONDITIONS } \\
\hline 7. I have gadget and internet connection to use "Catch and Keep" through Wordwall. & 100 & & \\
\hline 8. I know how to play the games in "Catch and Keep" through Wordwall. & 100 & & \\
\hline \multicolumn{4}{|l|}{ BEHAVIORAL INTENTION } \\
\hline 9. I would like to use "Catch and Keep" through Wordwall in my future learning activities. & 96.67 & 3.33 & \\
\hline 10. Learning vocabulary through "Catch and Keep" through Wordwall is a good idea. & 96.67 & 3.33 & \\
\hline
\end{tabular}

Table two: Participants' Insight on C\&K via Wordwall

Table two represents thirty participants' thoughts on the game "C\&K." According to the Unified Theory of Acceptance and Use of Technology (UTAUT) framework, the majority of the participants have efficacious and positive answers toward the implementation as in terms of assisting them in improving their vocabulary mastery. The performance expectancy of the C\&K innovation was tested, and all participants agreed that it increased their vocabulary. Additionally, they all believe that the innovation has enhanced their excitement for learning English. Participants also portray a good or positive behaviour toward endeavour demands, with twenty nine out of thirty participants admitting C\&K is simple to utilise or practise and one participant disagree with the statement. Furthermore, only one of them is undecided about the idea, while the others agree; not enjoyable when using C\&K via wordwall.

Majority of the participants also agree that this innovation is the latest and modernized way of learning approach. Besides, twenty three out of thirty participants were also in favour with the statement where teacher, friends and family encourage them in utilising C\&K via wordwall, while only seven undecided. Enabling elements are associated with high adoption rates, with $100 \%$ admitting that they are equipped with facilities and internet connection which enable them to participate in the intervention, thirty percent in favour that they do have the expertise and capable of playing "C\&K" games modules by themselves. Finally, only one out of every 30 responders is undecided about whether or not they would integrate or take part in the innovation in the upcoming classroom activities, while the rest are certain. Learning vocabulary with Wordwall's "C\&K" game is an excellent idea, according to 96.67 percent of respondents. As quoted by (Laremenko, 2017; Yunus et al., 2019), gamification in education is both motivating, exciting at the same time. This fact is also supported by Azli et al., (2015); Letchumanan et al., (2015) who stated that pupils enjoy studying English better if they play online games. To conclude, based on the UTAUT paradigm, participants receive constructive comments or feedback where they are driven to utilise "C\&K" in their future classroom activities.

In a nutshell, it is proven that pupils motivation in learning English shows positive feedbacks. According to (Shakir et al., 2020). ESL learners have a higher tendency to have a positive attitude and higher motivation in learning English when they are provided with 
supporting environmental elements such as supports from parents, peers and teachers. Besides, the importance of motivation in enhancing second language learning cannot be underestimated (Jemima et al., 2017). According to Williyam et al (2016), using games to draw pupils' attention and motivate them is beneficial because games allow social interaction with other pupils in virtual learning. As a result, the use of gamification in education enhanced student motivation since they enjoyed learning English vocabulary through games in class.

\section{Recommendations and Conclusion}

To conclude, the use of $C \& K$ has aided Year 3 children in improving their vocabulary proficiency. The fact that an increase of scores in the post test indicated that C\&K has a positive impact on pupils' vocabulary level hence C\&K should be employed in the teaching and learning sessions. Furthermore, the response to the use of $C \& K$ has been overwhelmingly positive, with the majority of participants feeling that C\&K is a good concept, hence it is also suggested for use in a regular face-to-face classroom. This study, on the other hand, is limited to pupils with reliable internet access and sufficient technology. Future research should focus on promoting the innovation to a larger audience. The innovation and this study are significant because they give a system of personalised games for the teaching and learning of English vocabulary that is beneficial to both students and teachers. Wordwall is a strong platform for using educational games in teaching and learning, thus having the right platform to use it is crucial.

Future research should look at the influence of C\&K on higher levels of education, such as secondary schools or postsecondary institutions. In order to have a positive effect through gamified learning, it is vital to understand the objective of integrating games in language learning sessions while also establishing means for integrating or producing educational games. In a nutshell, C\&K has proved successful in capturing and sustaining vocabulary knowledge as it works as a form of motivation as well during distant learning in a pandemic.

\section{References}

Alqahtani, M. (2015). The Importance of Vocabulary in Language Learning and How to be taught. International Journal of Teaching and Education, 3, 21-34. 10.20472/TE.2015.3.3.002.

Ashrafzadeh, A., \& Nimehchisalem, V. (2015). Vocabulary knowledge: Malaysian tertiary level learners' major problem in summary writing. Journal of Language Teaching and Research. 6(2): 286. doi:10.17507/jltr.0602.07.

Atikah, D., \& Rezki, A. (2018). Repetition facilitates retrieval opportunities in vocabulary learning. IOP Conference Series. Earth and Environmental Science, 175(1), 1-7. Available at: 10.1088/1755-1315/175/1/012148

Chee, K. M., Tan, K. H. (2021) QR Codes as A Potential Tool In Teaching And Learning Pronunciation: A Critical Review. Higher Education and Oriental Studies (HEOS). Vol 1(1): $31-44$

Çil, E. (2021). The Effect of Using Wordwall.net in Increasing Vocabulary Knowledge of 5th Grade EFL pupils. Language Education and Technology, 1(1), 21-28. Retrieved from http://www.langedutech.com/letjournal/index.php/let/article/view/16

Cruea, M. (2020). "Gaming the Mind and Minding the Game: Mindfulness and Flow in Video Games," in Video Games and Well-Being, ed. Kowert R. (Macmillan: Palgrave;), 97-107. 10.1007/978-3-030-32770-5_7 
Dong, C., Cao, S., \& Lia, H. (2020). Young children's online learning during COVID-19 pandemic: Chinese parents' beliefs and attitudes. Children and Youth Services Review. Vol 118. https://doi.org/10.1016/j.childyouth.2020.105440

Govindasamy, P., Hashim, H., Yunus, M. (2019).Mobile Assisted Vocabulary Learning: Examining The Effects on pupils' Vocabulary Enhancement. Universal Journal of Educational Research 7(12A):85-92.DOI:10.13189/ujer.2019.071911

Hashim, H., Yunus, M. M., Embi, A. M., \& Ozir, M. N. A. (2017). Mobile-assisted Language Learning (MALL) for ESL Learners: A Review of affordances and constraints. Sains Humanika, 9(1-5). https://doi.org/10.11113/sh.v9n1-5.1175.

Hasram, S., Nasir, M. K. (2021). The Effects of Wordwall Online Games (WOW) on English Language Vocabulary Learning Among Year 5 Pupils.Theory and Practise in Language Studies.ISSN 1799-2591 Volume 11, Number 9, September 2021. https://doi:10.18844/cjes.v13i2.752

Kanellopoulou, C., Kermanidis, K. L., \& Giannakoulopoulos, A. (2019). The dual-coding and multimedia learning theories: Film subtitles as a vocabulary teaching tool. Education Science, 9(210), 1-13. Available at: https://doi.org/10.3390/educsci9030210.

Nejati, E., \& Jahangiri, A. (2018). The effect of using computer assisted language learning (CALL) on Iranian EFL learners' vocabulary learning: An experimental study. Cypriot Journal of Educational Sciences 13(2): 113-124.

Nieto-Escamez, F. A., \& Roldán-Tapia, M. D. (2021). Gamification as Online Teaching Strategy During COVID-19: A Mini-Review. Frontiers in psychology, 12, 648552. https://doi.org/10.3389/fpsyg.2021.648552

Nuroh, E. Z., Retnaningdyah, P., Munir, A. (2021). Engaging young learners of English with multilingual digital storytelling (MDST) during covid-19 school closure. Journal of English Educators Society. 6:1. doi:10.21070/jees.v6i1.1145

OECD. (2016), Innovating Education and Educating for Innovation: The Power of Digital Technologies and Skills, OECD Publishing, Paris. http://dx.doi.org/10.1787/9789264265097-en

Richards and Landers. (2015). Developing a Theory of Gamified Learning. Available from: https://www.researchgate.net/publication/268632276_Developing_a_Theory_of_ Gamified_Learning [accessed Oct 05, 2021].

Sabbah, S. S. (2015). The Effect of College pupils' Self-Generated Computerized Mind Mapping on Their Reading Achievement. International Journal of Education and Development using Information and Communication Technology, 11(3), 4-36.

Shakir, A. A., Harwati, H., \& Yunus, M. M. (2020). Pupils' Motivation and Perceptions on ESL Lesson Through Online Quiz-Games. Journal of Education and e-Learning Research Vol. 7, No. 3, 229-234, 2020 ISSN(E) 2410-9991 / ISSN(P) 2518-0169 DOI: 10.20448/journal.509.2020.73.229.234

Sivagnanam, S., \& Yunus, M. M. (2020). Utilizing Social Media in Vocabulary Enhancement among Primary ESL Learners.Universal Journal of Educational Research 8(2): 490-498.DOI:10.13189/ujer.2020.080220

Sidek, H. M., \& Rahim, H. A. (2015). The Role of Vocabulary Knowledge in Reading Comprehension: A Cross -LinguisticStudy. Procedia- Social and Behavioral Sciences

Toh, W., \& Kirschner, D. (2020). Self-Directed Learning in Video Games, Affordances and Pedagogical Implications for Teaching and Learning. Comput. Educ. 154103912. 10.1016/j.compedu.2020.103912 
Valkenburg, P., \& Peter, J. (2009). Social Consequences of the Internet for Adolescents: A Decade of Research. Curr. Dir. Psychol. Sci. 18 1-5. 10.1111/j.1467-8721.2009.01595.x Vartanian, O., \& Beatty, E. (2015). Cognitive brain training, video games, and creativity. Video Games and Creativity 2015 185-198. 10.1016/B978-0-12-801462-2.00009-6

Waytz, A., Gray, K. (2018). Does Online Technology Make Us More or Less Sociable? A Preliminary Review and Call for Research. Perspect. Psychol. Sci. 13 473-491. 10.1177/1745691617746509

Wong, P. M., Yunus, M. M. (2020). Enhancing Writing Vocabulary Using Mentimeter. International Journal of Learning, Teaching and Educational Research Vol. 19, No. 3, pp. 106-122, March 2020 https://doi.org/10.26803/ijlter.19.3.7 